\title{
OS PROJETOS PEDAGÓGICOS DO CURSO DE ESPECIALIZAÇÃO DO PROEJA DO SUL DO BRASIL
}

\section{Neura Maria Weber Maron}

Universidade Federal do Paraná

\section{Domingos Leite Lima Filho}

Universidade Tecnológica Federal do Paraná

\section{Resumo}

Neste artigo, analisamos o documento "Proposta de Curso de Especialização do PROEJA" da SETEC/MEC (BRASIL, 2006b), em especial no que se refere à organização de seu conteúdo programático. Fazemos uma análise comparativa entre as orientações contidas neste documento e os projetos pedagógicos dos Cursos de Especialização do PROEJA desenvolvidos nos três estados do sul do Brasil. Trata-se de uma pesquisa documental sobre uma modalidade específica de formação docente que integra o Programa Nacional de Integração da Educação Profissional com a Educação Básica na Modalidade de Educação de Jovens e Adultos. Concluímos que apesar da formação de professores para a Educação Profissional e da Educação de Jovens e Adultos ter recebido significativos investimentos do governo federal, não recebeu o equivalente acompanhamento da SETEC/MEC em seu desenvolvimento, revelando certa fragilidade das universidades na organização e oferta dessa formação continuada aos professores.

Palavras-chave: Formação docente; PROEJA; Projetos pedagógicos de curso de especialização. 


\title{
THE PEDAGOGICAL PROJECTS OF PROEJA'S SPECIALIZATION COURSE FROM SOUTHERN BRAZIL
}

\begin{abstract}
In this paper we analyze the SETEC/MEC document "PROEJA's Specialization Course Proposal" (BRASIL/2006b), especially in what concerns its programmatic content. It is a comparative analyzes between the orientation provided within this document and the pedagogical projects, which were developed in the three southern states of Brazil, from the PROEJA Specialization Course Proposal. This is a documental research about a teacher's education modality which is part of the National Programme that integrates Vocational Education with Basic Education for Adult and Young people. In conclusion, although teachers' education of Vocational Education and Education for Adult and Young people has received significant investments from the federal government, received no follow-up equivalent of Setec/MEC in its development, revealing certain fragility from the universities when it comes to organize and propose teachers' continued education program.
\end{abstract}

Keywords: Teacher education, PROEJA, Pedagogical projects of specialization course. 


\section{Introdução}

A formação inicial e continuada de professores para atuar na educação profissional e tecnológica (EPT) segue sendo um tema central no debate educacional, uma vez que persistem lacunas históricas a este respeito nas políticas educacionais brasileiras. A ausência de regulamentações específicas e a ocorrência de programas pontuais de formação docente, apresentados inicialmente como emergenciais, mas que, ao longo de décadas, desde o início dos anos de 1970, são reiterados com modificações tópicas, caracterizam as marcas da fragmentação e da precariedade.

A questão se torna ainda mais complexa nos dias atuais, dada a vigência de programas de expansão da educação profissional e tecnológica, dentre eles o Programa Nacional de Educação Básica Integrada à Educação Profissional na Modalidade de Educação de Jovens e Adultos - PROEJA (BRASIL, 2006a). Desde sua criação em 2006, as Instituições da Rede Federal de Educação Profissional e Tecnológica, algumas delas em parceria com as Universidades Federais, se constituíram em Unidades-Polo ${ }^{1}$ de formação nos estados atendendo ao desafio da Setec/MEC de ofertar cursos de especialização como uma das ações de formação docente que integrou o programa.

Esta realidade traz novos contornos quantitativos e, sobretudo, qualitativos, considerando-se a especificidade da formação de docentes para trabalhar com jovens e adultos trabalhadores na educação básica nos níveis do ensino fundamental e do ensino médio.

Neste artigo, situamos e analisamos o documento "Proposta de Curso de Especialização do PROEJA” da SETEC/MEC (BRASIL, 2006b), em especial no que se refere à organização de seu conteúdo programático e as concepções do processo formativo desta modalidade de oferta de

\footnotetext{
${ }^{1}$ No sul do Brasil foram Unidades-Polo de formação, a Universidade Tecnológica Federal do Paraná - UTFPR que ofertou o curso em sete campi, o Instituto Federal de Santa Catarina - IFSC que ofertou o curso em cinco campi, e o consórcio de Instituições de Ensino Superior do Rio Grande do Sul (Centros Federais de Educação Tecnológica - CEFET/RS-IFRS, a Universidade Federal do Rio Grande do Sul, a Universidade Federal de Pelotas e a Escola Agrotécnica Federal de Alegrete) que ofertou o curso em sete cidades.
}

Olh@res, Guarulhos, v. 2, n. 2, p. 154-178. Dezembro, 2014. 
formação continuada aos professores e gestores das escolas públicas brasileiras. Em seguida fazemos uma análise comparativa entre as orientações contidas neste documento e os projetos pedagógicos dos cursos de especialização desenvolvidos nas três Unidades-Polo de formação docente do sul do Brasil.

Trata-se de uma pesquisa documental, a respeito de uma modalidade específica de formação docente que integra o Programa Nacional de Integração da Educação Profisssional com a Educação Básica na Modalidade de EJA, fruto do levantamento de documentos publicados pelas IES em suas páginas eletrônicas, e alguns disponibilizados pelos coordenadores dos cursos de especialização, por solicitação, via correio eletrônico, à pesquisa.

O estudo da formação docente ao PROEJA é parte integrante de pesquisa mais ampla, se constitui em um dos temas/objetos de investigação do projeto de pesquisa interinstitucional (UTFPR/UFPR/UNIOESTE) liderado pela UTFPR "Demandas e Potencialidades do PROEJA no Estado do Paraná” do Edital PROEJA/CAPES/SETEC n. ${ }^{\circ}$ 03/2006 (LIMA FILHO, 2007), e resultou na Tese de Doutorado "Os cursos de especialização para formação docente do PROEJA: a tecitura da oferta e dos resultados na percepção de cursistas da região sul do Brasil” (MARON, 2013).

\section{O curso de especialização do PROEJA proposto pela SETEC/MEC}

O documento que apresenta a Proposta de Curso de Especialização do PROEJA e que subsidia e orienta a implantação desse curso de pósgraduação lato sensu em todo o Brasil (BRASIL, 2006b) traça objetivos gerais e específicos voltados à formação de quadros de profissionais qualificados para atuar nesta modalidade de oferta educacional.

Embora neste documento esteja a afirmação de que esse processo de formação de docentes e gestores não ocorrerá de forma tão imediata, ao mesmo tempo se entende que os Cursos de Especialização do PROEJA são os desencadeadores de uma formação que objetiva a consolidação de um perfil profissional diferenciado.

Olh@res, Guarulhos, v. 2, n. 2, p. 154-178. Dezembro, 2014. 
Com a proposição do Curso de Especialização do PROEJA objetivase, portanto, a formação de especialistas docentes e gestores e, de ambos, espera-se que com essa formação ocorra a produção de novos conhecimentos teóricos e práticos que impulsionem a implementação da proposta do PROEJA. Em seu objetivo geral de curso define que pretende

\begin{abstract}
Formar profissionais com capacidades para atuar na elaboração de estratégias, no estabelecimento de formas criativas das atividades de ensino-aprendizagem e de prever proativamente as condições necessárias e as alternativas possíveis para o desenvolvimento adequado da educação profissional técnica de nível médio integrada ao ensino médio na modalidade Educação de Jovens e Adultos, considerando as peculiaridades, as circunstâncias particulares e as situações contextuais concretas em que programas e projetos deste campo são implementados. (BRASIL, 2006b, p. 5).
\end{abstract}

Por meio desta formação docente se pretende atingir três objetivos específicos que, embora se identifiquem entre si e até sejam complementares, são bastante distintos. $\mathrm{O}$ primeiro diz respeito especificamente ao perfil de egresso. Este programa de formação docente se propõe a formar especialistas da educação. Para isso o programa pretende desenvolver conhecimentos, habilidades, atitudes e valores pertinentes à atividade da docência no PROEJA que, conforme anunciado no objetivo geral, devem possibilitar a formação de profissionais com capacidades para atuar na elaboração de estratégias, no estabelecimento de formas criativas das atividades de ensino-aprendizagem e com mais aporte de conhecimentos a docência no PROEJA.

O segundo objetivo desta formação é capacitar gestores para uma implantação democrática, participativa e socialmente responsável de projetos educacionais para o desenvolvimento de estratégias, controle e organização do PROEJA. Percebemos que neste objetivo o curso de especialização se apresenta como uma estratégia de indução da implantação do PROEJA. Já o terceiro objetivo apresenta a preocupação com a produção de novos conhecimentos numa nova área educacional advinda da integração destas duas modalidades de ensino.

Olh@res, Guarulhos, v. 2, n. 2, p. 154-178. Dezembro, 2014. 
Justifica-se esta proposição de curso pela necessidade de se consolidar uma política de formação continuada de docentes, pois existe uma

escassez, na formação superior, em especial naquela voltada para o magistério, da abordagem de temas que contemplem as questões que permeiam o PROEJA, tais como a relação trabalho-educação; a gestão democrática participativa; os currículos integrados na direção da formação unitária; as especificidades da educação do campo; direitos humanos, diversidade e inclusão (BRASIL, 2006b, p. 8).

Em sua concepção de curso, apresenta três pressupostos (BRASIL, 2006a, p. 10). O primeiro pressuposto que fundamenta a concepção, se identifica com os objetivos do programa de formação docente, mas apresenta três perfis de egresso ou, se assim é possível compreender, um egresso com um perfil muito complexo e idealizado, sobretudo se considerarmos as peculiaridades oferecidas por um curso de especialização. O objetivo do programa é formar especialistas da educação com capacidades para atuar na elaboração de estratégias criativas para as atividades de ensino-aprendizagem. Segundo este pressuposto, o egresso poderá atuar no PROEJA como um docente-pesquisador; um gestor educacional de programas e projetos; e um formulador e executor de políticas públicas. Portanto, essa ampliação de perfil nos permite entender que o curso pretende formar um especialista que, independente de onde ele venha a atuar na estrutura de ensino, saberá atuar no sentido da implantação da política do PROEJA.

O segundo pressuposto fundamenta todas as ações do PROEJA e do EM integrado, ou seja, a integração entre trabalho, ciência, técnica, tecnologia, humanismo e cultura geral, e que demanda uma metodologia que integre teoria e prática, na busca da realização da práxis pedagógica.

Em seguida, coerentemente, são retomados os princípios do Documento Base do PROEJA e reafirmados alguns desses princípios, dando sustentação fillosófica e pedagógica à concepção de formação em nível de especialização, como a compreensão do trabalho como princípio educativo; a pesquisa como fundamento da formação do sujeito; e a necessidade de se conhecer o público da EJA considerando as condições geracionais, de Olh@res, Guarulhos, v. 2, n. 2, p. 154-178. Dezembro, 2014. 
gênero, de relações étnico-raciais como fundantes da formação humana e dos modos como se produzem as identidades sociais (BRASIL, 2006a, p. 38).

A partir desses três pressupostos, de modo a permitir maior flexibilidade na organização das propostas dos cursos, o documento apresenta a organização dos conteúdos programáticos em cinco eixos curriculares que, por sua vez, trazem uma listagem de conteúdos básicos a serem desenvolvidos. Segundo Burnier e Cunha (2005),

\begin{abstract}
A estruturação curricular por eixos tem como meta possibilitar a flexibilização e a agilidade na atualização dos conteúdos e das práticas curriculares, ao mesmo tempo em que busca garantir uma unidade de conhecimento centrada no foco do curso, preservando seu aspecto acadêmico. [...] Um "eixo de conteúdos e atividades" consiste na descrição dos conteúdos de uma grande área de conhecimento que o currículo visa abranger, constituindo-se na soma destas na macrounidade que a instituição oficializa como sendo o currículo do curso (BURNIER; CUNHA, 2005, p. 36).
\end{abstract}

Portanto, neste modelo, as macrounidades a partir das quais se pretende garantir que a unidade esteja centrada no foco do curso são: Concepções e princípios da educação profisssional e da educação básica na modalidade de educação de jovens e adultos; Gestão democrática e economia solidária; Políticas e legislação educacional; Concepções curriculares na educação profisssional e na educação básica na modalidade de educação de jovens e adultos; e Didáticas na educação profissional e na educação de jovens e adultos, conforme quadro a seguir apresentado. $\mathrm{O}$ documento propõe ainda que em cada eixo do curso de especialização se construa uma síntese da discussão entre ciência, tecnologia, natureza, cultura e trabalho, dimensões que são indissociáveis na vida real, mantendose o foco do curso.

Quadro 1 - A proposta do curso de especialização do PROEJA da SETEC/MEC

\begin{tabular}{|c|l|}
\hline $\begin{array}{c}\text { EIXO } \\
\text { CURRICULAR }\end{array}$ & \multicolumn{1}{c|}{ CONTEÚDOS } \\
\hline $\begin{array}{c}\text { Concepções e } \\
\text { princípios da } \\
\text { educação }\end{array}$ & $\begin{array}{l}\text { Função social da educação, da escola, da educação básica e da educação profissional e da educação de } \\
\text { jovens e adultos. Sentidos e concepções históricas para a educação básica, educação profissional e } \\
\text { educação de jovens e adultos, sistematizadas nos marcos legais nacionais e internacionais. O princípio }\end{array}$ \\
\hline
\end{tabular}

Olh@res, Guarulhos, v. 2, n. 2, p. 154-178. Dezembro, 2014. 


\begin{tabular}{|c|c|}
\hline $\begin{array}{l}\text { profissional e da } \\
\text { educação básica } \\
\text { na modalidade de } \\
\text { educação de } \\
\text { jovens e adultos }\end{array}$ & $\begin{array}{l}\text { do desenvolvimento integral e harmônico da personalidade do educando. O princípio da importância } \\
\text { socioeconômica da educação. O princípio da importância sociopolítica da educação. O princípio da } \\
\text { importância sociocultural da educação. Pressupostos e princípios da pedagogia tradicional, da escola } \\
\text { nova, do tecnicismo, do construtivismo, da pedagogia crítica sócio-histórica, do sociointeracionismo, } \\
\text { entre outras tendências pedagógicas. }\end{array}$ \\
\hline $\begin{array}{c}\text { Gestão } \\
\text { democrática e } \\
\text { economia } \\
\text { solidária }\end{array}$ & $\begin{array}{l}\text { Relação entre gestão e qualidade da educação. Pressupostos e princípios da gestão democrática da } \\
\text { educação. Gestão de programas e projetos educacionais. Projeto político-pedagógico como } \\
\text { instrumento de gestão democrática. Processos de construção de projetos político-pedagógicos. Gestão } \\
\text { e organização de tempos e espaços escolares. Mecanismos de consulta e de controle social da } \\
\text { educação. Articulação da gestão da educação com outras políticas setoriais. Articulação da gestão da } \\
\text { educação com movimentos sociais. Avaliação institucional da educação e da escola. Pressupostos, } \\
\text { princípios, métodos e diretrizes. Cooperativismo e economia solidária. }\end{array}$ \\
\hline $\begin{array}{c}\text { Políticas e } \\
\text { legislação } \\
\text { educacional }\end{array}$ & $\begin{array}{l}\text { Produção histórica dos marcos políticos e legais das áreas envolvidas: Processos de luta e conquista } \\
\text { social. Quadro político e legal da educação profissional técnica de nível médio e da formação inicial e } \\
\text { continuada (qualificação profissional). Quadro político e legal da educação básica na modalidade de } \\
\text { educação de jovens e adultos. O marco da educação inclusiva como referência para repensar as } \\
\text { construções políticas e legais nessas áreas, marco regulatório da educação escolar indígena, } \\
\text { referenciais para a educação do campo, referenciais para a educação em direitos humanos, para a } \\
\text { diversidade e inclusão social. }\end{array}$ \\
\hline $\begin{array}{c}\text { Concepções } \\
\text { curriculares na } \\
\text { educação } \\
\text { profissional e na } \\
\text { educação básica } \\
\text { na modalidade de } \\
\text { educação de } \\
\text { jovens e adultos }\end{array}$ & $\begin{array}{l}\text { Diferenças entre teoria e fato curricular. Conceitos de currículo. Concepções de currículo como } \\
\text { microexperiências centradas na vida escolar. Concepções de currículo como experiências } \\
\text { macrossociais nas quais a vida escolar se insere e se produz. Sujeitos de diferentes aprendizagens } \\
\text { como produtores de currículo no cotidiano da prática pedagógica. Currículo: resultados e processos, } \\
\text { realidades interativas e normas, projetos e realidades, exigências sociais e condições sociais. } \\
\text { Produção curricular: emergência de currículos e resgate da realidade social e cultural dos educandos. } \\
\text { Modelos disciplinares, modulares e integradores de currículos. Objetivos do processo ensino- } \\
\text { aprendizagem como orientadores da seleção ordenamento e estruturação de conteúdos. Lógicas de } \\
\text { estruturação de conteúdos. Determinação de nexos, relações e concatenações dos conhecimentos em } \\
\text { correspondência com as particularidades do desenvolvimento dos educandos e com as necessidades } \\
\text { de conhecer os objetos de conhecimento. Problemas epistemológicos na concepção dos currículos da } \\
\text { educação profissional técnica de nível médio e do ensino médio na modalidade educação de jovens e } \\
\text { adultos. Desenhos curriculares na educação profissional técnica de nível médio e no ensino médio na } \\
\text { modalidade educação de jovens e adultos e alternativas de interaçãa. }\end{array}$ \\
\hline $\begin{array}{l}\text { Didáticas na } \\
\text { educação } \\
\text { profissional e na } \\
\text { educação de } \\
\text { jovens e adultos }\end{array}$ & $\begin{array}{l}\text { Relação entre objetivos, conteúdos, métodos, forma de organização, carga horária, meios didático- } \\
\text { pedagógicos e avaliação no processo de ensino-aprendizagem. Princípios didático-pedagógicos que } \\
\text { fomentam a unidade e os nexos entre educação profissional e educação básica na modalidade de } \\
\text { educação de jovens e adultos. Tempos de aprendizagem e conteúdos na educação de jovens e adultos. } \\
\text { Implicações para a relação entre conteúdo-método-forma de organização-meio e para a relação entre } \\
\text { conteúdo-princípios didáticos. Estratégias didáticas integradoras. O modelo de unidades de ensino } \\
\text { integradas, o método de projetos, eixos temáticos, temas geradores e transversais, investigações } \\
\text { interdisciplinares, etc.. Estratégias metodológicas focalizadas: na dinamização da atividade } \\
\text { cognoscitiva dos alunos, na estimulação da autonomia discente, que exercitem a criatividade e a } \\
\text { capacidade de aplicar e transferir conhecimentos adquiridos a novas situações de resolução de } \\
\text { problemas, de fixação de aprendizagens e que trabalhem sentimentos e emoções. }\end{array}$ \\
\hline
\end{tabular}

Fonte: Elaboração a partir da "Proposta de Curso de Especialização do PROEJA" (BRASIL, 2006b).

Este quadro apoiará a análise dos Projetos Pedagógicos de Curso de Especialização do PROEJA na continuidade, o que significa dizer que, apesar de não estarmos validando o proposto, o estamos considerando como uma possibilidade. Especialmente quando se afirma que na formação dos docentes da educação técnico-profissional do PROEJA se pretende que sejam considerados todos os aspectos que envolvem as temáticas do mundo do trabalho e da realidade social na qual o educando trabalhador aluno dos cursos PROEJA está concretamente situado.

Olh@res, Guarulhos, v. 2, n. 2, p. 154-178. Dezembro, 2014. 
Os projetos pedagógicos dos cursos nas três Unidades-Polo do sul do Brasil

Para a análise dos projetos pedagógicos dos cursos nas três Unidades-Polo do sul do Brasil tomamos os elementos básicos da organização curricular: os objetivos gerais e específicos, a concepção do programa, os cinco eixos curriculares e os conteúdos programáticos. Buscamos compreender a estrutura da oferta deste curso, fazendo a contraposição com estes mesmos elementos encontrados na Proposta de Curso de Especialização do PROEJA (BRASIL, 2006b) da SETEC/MEC. A atenção estará voltada às dimensões doutrinal (princípios e concepções) e operacional, que é a apresentação da organização curricular com vistas à operacionalização da proposta.

De maneira geral, as três Unidades-Polo seguem a mesma estrutura sugerida pela SETEC/MEC para a organização dos projetos pedagógicos do curso, além de reproduzirem fielmente o conteúdo de alguns itens. Assumem o contido da proposta e adotam a mesma linguagem no que se refere à justificativa, aos objetivos e aos princípios, no entanto, apresentam peculiaridades no momento de contemplar as temáticas propostas nos cinco eixos curriculares.

As Unidades-Polo dos três Estados adotam os objetivos integralmente em seus projetos pedagógicos. O IFSC, ao adotá-los, acrescenta ainda que "considera-se, também, a implantação do PROEJA em todo o Estado" (IFSC, 2007, p. 6). Isso tem importância na medida em que a instituição se compromete com uma formação docente direcionada à atuação junto a uma demanda concreta a ser atendida no Estado, com a implantação do PROEJA.

Observamos que no Paraná a Unidade-Polo da UTFPR campus Curitiba adota esses objetivos integralmente, mas o projeto do campus de Londrina, ao qual tivemos acesso, não traz o segundo objetivo, que trata da produção de conhecimentos na área do PROEJA. Embora este objetivo não

Olh@res, Guarulhos, v. 2, n. 2, p. 154-178. Dezembro, 2014. 
se faça presente no projeto, ao prever a pesquisa e a elaboração de monografias de conclusão de curso, a produção de novos conhecimentos é contemplada.

Os projetos da Unidade-Polo do consórcio do Rio Grande do Sul e da Unidade-Polo do IFSC inicialmente adotam os três objetivos específicos, mas, em 2009, substituem o objetivo de produzir conhecimentos pelo objetivo de colaborar no desenvolvimento de currículos integrados, o que tem diferentes implicações e incidências diferenciadas, embora ambas sejam complementares. No entanto, parece-nos evidente que a primeira formulação é mais ampla que a segunda, tanto na questão operativa quanto na amplitude temática, posto que "produzir conhecimentos" como síntese da formulação e implementação "teórico-prática" extrapola em muito o colaborar no "desenvolvimento de currículos".

Com relação à concepção de um programa e seus pressupostos pudemos constatar que no documento do projeto de curso da Unidade-Polo da UTFPR a concepção explicita o primeiro e o terceiro pressupostos do programa (UTFPR, 2006, p. 6). No entanto, justamente o pressuposto que trata da integração entre trabalho, ciência, técnica, tecnologia, humanismo e cultura geral não foi adotado. Não temos elementos para afirmar se a IES não adotou esse pressuposto como forma de exercer sua autonomia pedagógica ou se este é um indício de um movimento de resistência a uma concepção de integração curricular ou mesmo um erro na transcrição dos pressupostos. No entanto, não apresentar e não acrescentar nenhum outro pressuposto em substituição a este pode ser evidência de resistência.

Já nos projetos pedagógicos dos cursos ofertados na Unidade-Polo do IFSC e do Rio Grande do Sul, os pressupostos da concepção do programa são integralmente adotados. Porém, a presença dos pressupostos da concepção do programa nos projetos pedagógicos dos cursos não significa necessariamente a adoção das mesmas pelas IES nos processos de desenvolvimento da formação docente. Essa postura de anunciar os pressupostos literalmente iguais pode significar simplesmente a transcrição dos mesmos, como forma de adesão fiel à linguagem de um documento, ou 
até mesmo pela necessidade de se adequar a uma proposta de formação com um orçamento próprio e que, portanto, dependia de aprovação da SETEC/MEC para sua execução. Entretanto, a análise dos conteúdos programáticos dos cursos, a seguir realizada, constitui subsídio importante para a verificação do entendimento aos referidos pressupostos.

\section{Os eixos curriculares e a organização do conteúdo programático}

Um dos objetivos desta organização curricular por eixos é possibilitar que em cada eixo se construa uma síntese da discussão entre ciência, tecnologia, natureza, cultura e trabalho que leve à compreensão da integração, fio condutor desta formação e um dos pressupostos da concepção do programa, tendo em vista a atuação dos egressos como docentes nas turmas de educação profissional integrada à educação básica na modalidade de EJA.

A seguir, faremos a análise da organização dos conteúdos dos cinco eixos curriculares presentes nos projetos de curso das três Unidades-Polo investigadas, buscando identificar elementos de adaptação, resistência, transcendência ou superação ao proposto, não perdendo de vista que a organização proposta pela SETEC/MEC era apenas uma sugestão para as IES organizarem o projeto pedagógico dos cursos.

Inicialmente, identificamos que a organização dos conteúdos listados nos cinco eixos nas três Unidades-Polo de formação sofreu uma evidente fragmentação dos conteúdos. Reconhecemos que a organização dos conteúdos programáticos do curso em eixos prevista na proposta era uma possibilidade de compreender a integração curricular. Portanto, se a proposta da SETEC/MEC de organização por eixos temáticos visava a uma formação integrada, as instituições formadoras pesquisadas ignoraram esta orientação e os docentes cursistas perderam a oportunidade de vivenciar uma formação menos fragmentada, o que poderia possibilitar uma compreensão mais aproximada do que é a integração curricular do ponto de vista teórico e prático, algo importante de ser compreendido para o docente

Olh@res, Guarulhos, v. 2, n. 2, p. 154-178. Dezembro, 2014. 
ser capaz de propor formas de efetivação do currículo integrado no PROEJA.

A Unidade-Polo da UTFPR adota as temáticas propostas para os cinco eixos, fragmenta-as em unidades curriculares e em seguida encontramos os conteúdos dispersos e elencados em ementas como listagens sintéticas de temas/conteúdos a serem abordados. Nele constatamos um misto de adaptação e resistência ao proposto pela SETEC/MEC.

A Unidade-Polo do IFSC adota as temáticas dos eixos, mas a nomenclatura é a de módulos, para em seguida fragmentar estas temáticas em componentes curriculares com suas respectivas ementas. A UnidadePolo do consórcio do Rio Grande do Sul organiza os conteúdos sugeridos em módulos, sem o cuidado de preservar a nomenclatura das temáticas. Vamos reencontrar os conteúdos dispersos nas ementas das disciplinas. No entanto, em todos os projetos a apresentação dos conteúdos é clara, permitindo uma visão geral dos conteúdos que foram previstos para serem desenvolvidos em cada uma delas, explicitando inclusive as horas determinadas para cada disciplina.

\begin{tabular}{|c|c|c|}
\hline $\begin{array}{c}\text { EIXOS } \\
\text { CURRICULARES }\end{array}$ & $\begin{array}{c}\text { UNIDADES } \\
\text { CURRICULARES }\end{array}$ & EMENTAS \\
\hline \multirow{6}{*}{\begin{tabular}{|c|} 
Eixo curricular 1 \\
Concepções e princípios \\
da educação \\
profissional, do ensino \\
médio e da educação de \\
jovens e adultos
\end{tabular}} & $\begin{array}{l}\text { Educação Profissional e de } \\
\text { Jovens e Adultos no contexto } \\
\text { da educação Brasileira }-15 \mathrm{~h}\end{array}$ & $\begin{array}{l}\text { Concepções históricas e marcos legais para o ensino médio, educação } \\
\text { profissional e educação de jovens e adultos. A Educação Profissional e a } \\
\text { Educação de Jovens e Adultos na sociedade atual. Articulação entre educação de } \\
\text { jovens e adultos e educação profissional: desafios e perspectivas. }\end{array}$ \\
\hline & $\begin{array}{l}\text { Paradigmas da Educação - } \\
\text { 30h }\end{array}$ & $\begin{array}{l}\text { Função social da educação, da escola, do ensino médio, da educação profissional } \\
\text { técnica de nível médio e da educação de jovens e adultos. Princípios da educação } \\
\text { Nacional. Tendências da educação Brasileira. }\end{array}$ \\
\hline & $\begin{array}{l}\text { Dimensões da Ciência e da } \\
\text { Tecnologia no Ambiente } \\
\text { Educacional }-15 \mathrm{~h} \\
\end{array}$ & $\begin{array}{l}\text { Relação entre Ciência, Sociedade e Tecnologia. Políticas de estado para Ciência e } \\
\text { Tecnologia. Qualidade e inovação. Paradigmas epistemológicos da ciência e da } \\
\text { tecnologia. A natureza e o papel da educação tecnológica no contexto social. }\end{array}$ \\
\hline & $\begin{array}{l}\text { Tecnologia aplicada }-30 \mathrm{~h} \\
\text { (só foi ofertada em 2006) }\end{array}$ & $\begin{array}{l}\text { Instrumentalização sobre tecnologias utilizadas no ambiente educacional da EJA. } \\
\text { Comportamento em sala de aula. Material didático próprio na intervenção de } \\
\text { aulas da EJA. Práticas pedagógicas com recursos tecnológicos em EJA. }\end{array}$ \\
\hline & Pesquisa em Educação - 10h & $\begin{array}{l}\text { Concepções de pesquisa e seus pressupostos teóricos e filosóficos. Tipos de } \\
\text { pesquisa. O professor como investigador de sua prática pedagógica. }\end{array}$ \\
\hline & Seminário integrador I $-10 \mathrm{~h}$ & Sem ementa. \\
\hline \multirow[t]{2}{*}{$\begin{array}{l}\text { Eixo curricular } 2 \\
\text { Gestão Democrática }\end{array}$} & $\begin{array}{c}\text { Projeto Político }- \\
\text { Pedagógico }-15 \\
\text { (só foi ofertada em 2006) }\end{array}$ & $\begin{array}{l}\text { Concepção, princípios e pressupostos do projeto político-pedagógico. Processos } \\
\text { de construção do projeto Político-Pedagógico. Projeto político-pedagógico como } \\
\text { instrumento de gestão. }\end{array}$ \\
\hline & Gestão educacional - 30h & $\begin{array}{l}\text { Relação entre gestão e qualidade da educação. Gestão educacional como } \\
\text { alternativa à administração escolar. Pressupostos e princípios da gestão } \\
\text { participativa na educação. Gestão de programas e projetos educacionais. } \\
\text { Articulação da gestão da educação com outras políticas setoriais. Articulação da } \\
\text { gestão da educação com movimentos sociais. Estrutura Organizacional das } \\
\text { Instituições de Ensino: Legislação do Ensino e orientações para as mudanças na } \\
\text { Legislação; Formação continuada. Política de desenvolvimento de Recursos } \\
\text { Humanos. Gestão e organização de tempos e espaços escolares. }\end{array}$ \\
\hline
\end{tabular}

Olh@res, Guarulhos, v. 2, n. 2, p. 154-178. Dezembro, 2014. 


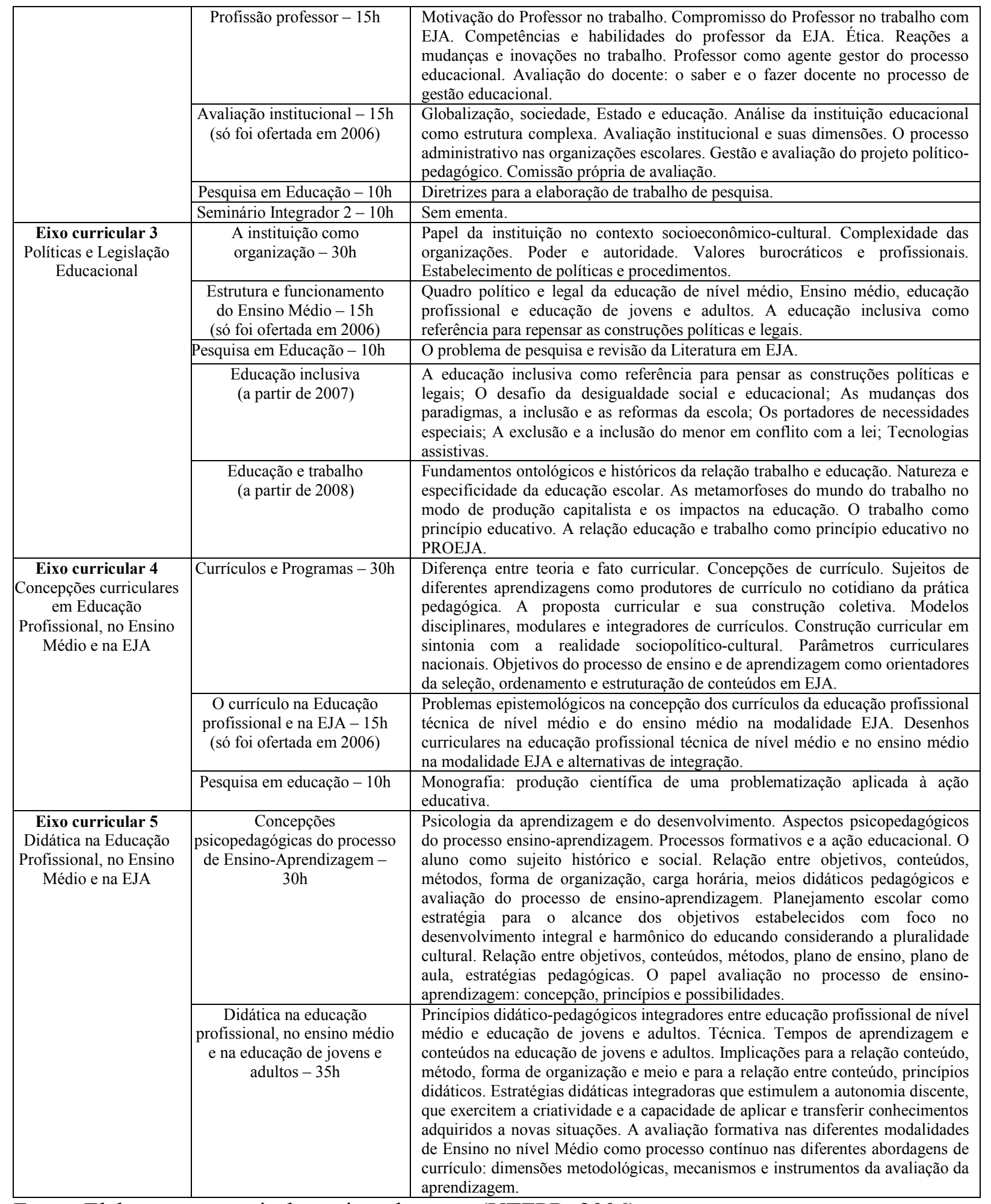

Fonte: Elaboração a partir do projeto de curso (UTFPR, 2006).

Olh@res, Guarulhos, v. 2, n. 2, p. 154-178. Dezembro, 2014. 
Constatamos que o projeto adota os nomes dos cinco eixos propostos, mas fragmenta este eixo em unidades curriculares e adota inclusive algumas disciplinas de seu já existente curso de Licenciatura Plena de Formação Docente do Programa Especial de Formação Pedagógica ${ }^{2}$ mesclando-as entre estes eixos, para em seguida inserir nas ementas destas unidades os conteúdos da Proposta de Curso de Especialização do PROEJA (BRASIL, 2006b).

Essa organização curricular assumida pela UTFPR para este curso de especialização, além de fragmentar os conteúdos dos eixos de maneira a descaracterizá-los, faz com que o especialista em PROEJA saia com uma certificação muito semelhante ao certificado emitido aos concluintes do Programa Especial de Formação Pedagógica ofertado pela instituição ${ }^{3}$.

Pudemos constatar ainda que, em alguns casos, as unidades curriculares apresentam a mesma ementa presente no curso de Licenciatura Plena de Formação Docente, como, por exemplo, a unidade curricular "A instituição como Organização", com carga horária de 30 horas. De semelhante modo, a unidade curricular "Profissão professor" apenas acrescenta dois itens novos na ementa aos conteúdos já existentes da licenciatura: Compromisso do Professor no trabalho com EJA. Competências e habilidades do professor da EJA. Ética. O mesmo ocorre com a unidade curricular "Dimensões da Ciência e da Tecnologia no Ambiente Educacional”, que reorganiza a ementa mantendo alguns conteúdos como, por exemplo, o item Qualidade e inovação. Esta constatação caracteriza a fragilidade deste processo formativo.

Nestas e em outras unidades curriculares, é pertinente admitir a aproximação entre os conteúdos da formação geral de licenciados com os conteúdos da formação continuada específica a professores do PROEJA; no entanto, tal aproximação, reduzindo-se a mera replicação do geral, acaba por

2 Disponível em: < http://www.cofop.utfpr.edu.br/discip.htm>. Acesso em 12 out. 2012.

3 Uma análise mais detalhada deste curso pode ser encontrada em: CLAUDINO, Jane Carla. Formação de professores para a educação tecnica de nível médio - Análise do programa especial de formação pedagógica da UTFPR. Dissertação (Mestrado em Tecnologia) - Universidade Tecnológica Federal do Paraná. Curitiba, 2010. Olh@res, Guarulhos, v. 2, n. 2, p. 154-178. Dezembro, 2014. 
não contemplar a situação da especificidade e diversidade dos sujeitos jovens e adultos.

Ao analisarmos o eixo "Gestão democrática", percebemos que, apesar de ser adotado o eixo, a economia solidária e o cooperativismo, dois temas que foram introduzidos na versão da Proposta de Curso de Especialização do PROEJA de 2008, não aparecem no itinerário formativo, algo que é muito caro à EJA, tendo em vista a inserção marginal de seus educandos na economia do país. Chama a atenção pela desarmonia a unidade curricular "Tecnologia aplicada", com carga horária de 30 horas no eixo "Concepções e princípios da educação profisssional, do ensino médio e da educação de jovens e adultos", cuja ementa explicita que vai se tratar também de "Instrumentalização sobre tecnologias utilizadas no ambiente educacional da EJA" e de "Práticas pedagógicas com recursos tecnológicos em EJA". Por outro lado a unidade curricular Seminário Integrador (num total de 20 horas) está fragmentada, de modo que se repete em dois eixos sem a especificação de conteúdos, o que não nos permite identificar quais foram os objetivos desses seminários.

Neste contraditório processo de organização curricular, onde identificamos um misto de adesão e resistência da Unidade-Polo da UTFPR, pudemos constatar que o discurso explicitado no Projeto Pedagógico não está plenamente referendado pela matriz curricular apresentada, havendo uma evidente desarmonia entre unidades curriculares, ementas, eixos, objetivos e princípios do PROEJA, caracterizando-se uma fragilidade na formação ofertada, em vista do foco desta formação. No entanto, uma positividade percebida na organização curricular da Unidade-Polo da UTFPR é a presença da unidade curricular "Educação e Trabalho" a partir da proposta de 2008, cuja listagem de temas contempla o trabalho como princípio educativo, conforme consta na ementa:

Fundamentos ontológicos e históricos da relação trabalho e educação. Natureza e especificidade da educação escolar. As metamorfoses do mundo do trabalho no modo de produção capitalista e os impactos na educação. $O$ trabalho como princípio educativo. A relação educação e trabalho como princípio educativo no PROEJA (UTFPR, 2010, p. 24).

Olh@res, Guarulhos, v. 2, n. 2, p. 154-178. Dezembro, 2014. 
No Projeto Pedagógico do Curso de Especialização do PROEJA da Unidade-Polo do IFSC, a organização curricular é apresentada em módulos e o conteúdo programático está fragmentado em componentes curriculares, e com os conteúdos explicitados nas ementas de cada componente curricular.

\section{Quadro 3 - O curso de especialização do PROEJA na Unidade-Polo do IFSC}

\begin{tabular}{|c|c|c|}
\hline MÓDULOS & $\begin{array}{c}\text { COMPONENTE } \\
\text { S } \\
\text { CURRICULARE } \\
\text { S }\end{array}$ & EMENTAS \\
\hline \multirow[t]{3}{*}{$\begin{array}{l}\text { Módulo 1 } \\
\text { Fundamentos da } \\
\text { educação foco: } \\
\text { Elevação da } \\
\text { Escolaridade e } \\
\text { Formação } \\
\text { Profissional. }\end{array}$} & $\begin{array}{l}\text { Eixos, Princípios e } \\
\text { Políticas de Educação } \\
\quad-30 \mathrm{~h}\end{array}$ & $\begin{array}{l}\text { História e educação. As origens da Educação. Educação e política. } \\
\text { Filosofia da educação brasileira. O referencial teórico da educação: educação como } \\
\text { processo social de integração, contradição e transformação da sociedade. Desenvolvimento } \\
\text { da sociedade brasileira e educação. A educação formal e informal como espaço político da } \\
\text { luta pela hegemonia. Relação entre educação e desigualdade social. Análise sócio-histórico- } \\
\text { filosófica das relações Trabalho, Cidadania e Educação. Sujeito e conhecimento. Função } \\
\text { social da escola, da EP profissional integrada à educação básica e da EJA. Lei de Diretrizes } \\
\text { e Bases da Educação. Legislação do EF e EM. Legislação da EP e Tecnológica. Legislação } \\
\text { de EJA. Decreto 5478/05. Desafios e perspectivas da Educação de Jovens e Adultos (EJA) } \\
\text { frente às transformações do mundo do trabalho. Movimentos sociais e suas contribuições } \\
\text { para a EJA. Paulo Freire e a prática da educação popular. }\end{array}$ \\
\hline & $\begin{array}{l}\text { Fundamentos, } \\
\text { concepção de EJA e } \\
\text { PROEJA }-30 \mathrm{~h}\end{array}$ & $\begin{array}{l}\text { Política educacional e EJA. As especificidades da EJA: concepções e modalidades. } \\
\text { Dimensões de formação da vida adulta. Os espaços e os tempos da EJA. O perfil } \\
\text { sociocultural dos educandos jovens e adultos e suas necessidades de aprendizagem. }\end{array}$ \\
\hline & $\begin{array}{ll}\text { Metodologia } & \text { da } \\
\text { Pesquisa }-30 \mathrm{~h}\end{array}$ & $\begin{array}{l}\text { A inter-relação pesquisa, leitura e escrita e a formação do professor pesquisador. A pesquisa } \\
\text { e o sentido de intervenção social do trabalho educativo. Exercícios e vivências pedagógicas: } \\
\text { Educação e trabalho (laboratório pedagógico). }\end{array}$ \\
\hline \multirow[t]{3}{*}{$\begin{array}{c}\text { Módulo 2 } \\
\text { Educação e } \\
\text { Currículo } \\
\text { Foco: } \\
\text { Integração } \\
\text { curricular: } \\
\text { educação } \\
\text { profissional, no } \\
\text { ensino } \\
\text { fundamental, } \\
\text { médio e na } \\
\text { educação de } \\
\text { jovens e adultos. }\end{array}$} & $\begin{array}{l}\text { O currículo integrado: } \\
\text { uma dialética entre a } \\
\text { formação geral e a } \\
\text { formação profissional } \\
-30 \mathrm{~h}\end{array}$ & $\begin{array}{l}\text { Conceitos de currículo: o currículo escolar como ferramenta imprescindível para se } \\
\text { compreender os interesses que atuam e estão em permanente jogo na escola e na sociedade. } \\
\text { Currículo como identidade da escola e dos que dela participam. A sala de aula como espaço de } \\
\text { interlocução e construção de conhecimentos. As concepções de interdisciplinaridade e o } \\
\text { trabalho interdisciplinar. A produção e a socialização do conhecimento e suas implicaçães na } \\
\text { organização de uma proposta curricular. Competências fundamentais ao exercício da cidadania } \\
\text { e à formação geral. A educação para a vida. Parâmetros Curriculares Nacionais para o Ensino } \\
\text { Médio. A base legal da educação profissional de Nível Técnico. Referenciais Curriculares da } \\
\text { Educação Profissional de Nível Técnico. A articulação entre a educação profissional e a } \\
\text { educação básica. A autonomia da escola e do aluno na integração curricular, favorecendo o } \\
\text { processo formativo contextualizado. }\end{array}$ \\
\hline & $\begin{array}{l}\text { Processos Pedagógicos } \\
-30 \mathrm{~h}\end{array}$ & $\begin{array}{l}\text { Análise sócio-histórico-filosófica das relações Trabalho, Cidadania e Educação. As } \\
\text { concepções de interdisciplinaridade e o trabalho interdisciplinar na Educação de Jovens e } \\
\text { Adultos. A produção e a socialização do conhecimento e suas implicações na organização } \\
\text { de uma proposta curricular de Educação de Jovens e Adultos. Concepçoses de conhecimento } \\
\text { e ação docente. Fundamentos teórico-metodológicos da aprendizagem de jovens e adultos. } \\
\text { Estratégias didáticas integradoras do conhecimento: unidades de ensino integradas, eixos } \\
\text { temáticos, projetos, temas geradores e transversais, investigações interdisciplinares. } \\
\text { Pedagogia das competências. }\end{array}$ \\
\hline & $\begin{array}{l}\text { Aval. aprendizagem: } \\
\text { Diagnósticos X } \\
\text { Classificação }-30 \mathrm{~h}\end{array}$ & $\begin{array}{l}\text { Concepção e princípios do trabalho educativo. Relações entre objetivos, métodos, } \\
\text { organização dos tempos e espaços e avaliação do trabalho educativo. Avaliação processual } \\
\text { da aprendizagem e avaliação da ação planejada. }\end{array}$ \\
\hline
\end{tabular}

Olh@res, Guarulhos, v. 2, n. 2, p. 154-178. Dezembro, 2014. 


\begin{tabular}{|c|c|c|}
\hline $\begin{array}{c}\text { Módulo 3 } \\
\text { Didática: } \\
\text { teóricas e } \\
\text { práticas } \\
\text { pedagógicas. } \\
\text { Foco: A ação } \\
\text { docente os os } \\
\text { processos de } \\
\text { aprendizagem } \\
\text { na educação } \\
\text { básica } \\
\text { modalidade EJA }\end{array}$ & $\begin{array}{l}\text { Teorias e práticas } \\
\text { Pedagógicas }-15 \mathrm{~h}\end{array}$ & $\begin{array}{l}\text { Concepções de conhecimento e ação docente. Fundamentos teórico-metodológicos da } \\
\text { aprendizagem de jovens e adultos. Estratégias didáticas integradoras do conhecimento: } \\
\text { unidades de ensino integradas, eixos temáticos, projetos, temas geradores e transversais, } \\
\text { investigações interdisciplinares. Pedagogia das competências. }\end{array}$ \\
\hline & $\begin{array}{l}\text { Planejamento, } \\
\text { sistematização e } \\
\text { avaliação do trabalho } \\
\text { educativo }-15 \mathrm{~h}\end{array}$ & $\begin{array}{l}\text { Concepção e princípios do trabalho educativo. Relações entre objetivos, métodos, } \\
\text { organização dos tempos e espaços e avaliação do trabalho educativo. Avaliação processual } \\
\text { da aprendizagem e avaliação da ação planejada. }\end{array}$ \\
\hline & $\begin{array}{l}\text { Ciência, trabalho e } \\
\text { tecnologia }-15 \mathrm{~h}\end{array}$ & $\begin{array}{l}\text { Concepção de ciência, trabalho e tecnologia. Nexos entre conceitos estruturantes das } \\
\text { diversas áreas de conhecimento e a sistematização do saber escolar. Possibilidades de } \\
\text { abordagens transdisciplinares e interdisciplinares. Construção de materiais didático- } \\
\text { pedagógicos relacionados à ciência, trabalho e tecnologia. }\end{array}$ \\
\hline & $\begin{array}{l}\text { Comunicação, cultura } \\
\text { e sociedade }-15 \mathrm{~h}\end{array}$ & $\begin{array}{l}\text { Linguagem: conceitos e abordagens. Cultura escrita e participação social. Letramento e } \\
\text { práticas linguísticas. Aprendizagem e ensino de língua materna. Possibilidades de } \\
\text { abordagens transdisciplinares e interdisciplinares. Construção de materiais didático- } \\
\text { pedagógicos voltados às práticas linguísticas. }\end{array}$ \\
\hline & $\begin{array}{l}\text { Educação matemática } \\
\text { e Cidadania - } 15 \mathrm{~h}\end{array}$ & $\begin{array}{l}\text { Saberes matemáticos, conteúdos escolares e mediação pedagógica. Conceitos fundamentais } \\
\text { da matemática para a participação social. Habilidades matemáticas e práticas de leitura e } \\
\text { escrita. Possibilidades de abordagens transdisciplinares e interdisciplinares. Construção de } \\
\text { materiais didático-pedagógicos. }\end{array}$ \\
\hline \multirow{4}{*}{$\begin{array}{c}\text { Módulo 4 } \\
\text { Gestão, Economia } \\
\text { Solidária e Inclusão } \\
\text { Foco: Princípios } \\
\text { e fundamentos } \\
\text { teórico- } \\
\text { metodológicos de } \\
\text { gestão democrática, } \\
\text { de economia } \\
\text { solidária e de } \\
\text { inclusão. }\end{array}$} & $\begin{array}{l}\text { Organização e gestão } \\
\text { educacional }-30 \mathrm{~h}\end{array}$ & $\begin{array}{l}\text { Pressupostos e princípios da gestão democrática. A gestão de programas e projetos } \\
\text { educacionais. Articulação da gestão da educação com movimentos sociais. Conceitos e } \\
\text { princípios de organização escolar. Cultura institucional e mudanças. Noções e princípios de } \\
\text { trabalho coletivo, autonomia e participação. Articulação entre trabalho administrativo e } \\
\text { pedagógico. Tempos e espaços escolares. Gestão de Equipes e Relacionamento Interpessoal. } \\
\text { Diretrizes legais, conceitos e fundamentos. Autonomia e desenvolvimento da escola. Processos } \\
\text { de construção do PPI e do PDI. }\end{array}$ \\
\hline & $\begin{array}{l}\text { Economia Solidária - } \\
15 \mathrm{~h}\end{array}$ & $\begin{array}{l}\text { Conceitos e princípios, teórico-práticos, relacionados à Economia Solidária. A Economia } \\
\text { Solidária, o Cooperativismo e a Autogestão em uma perspectiva histórica. O que a } \\
\text { Economia Solidária engloba. Princípios do Cooperativismo. Características e objetivos das } \\
\text { cooperativas. Os desafios da Autogestão. A economia solidária na Educação de Jovens e } \\
\text { Adultos. }\end{array}$ \\
\hline & $\begin{array}{l}\text { Seminários: Inclusão, } \\
\text { Diversidade }-45 \mathrm{~h}\end{array}$ & $\begin{array}{l}\text { Diretrizes legais. Legislação e levantamentos estatísticos da situação brasileira. Concepção } \\
\text { de programas de inclusão. A Diversidade na educação brasileira. A educação profissional e } \\
\text { o PROEJA como forma de mudar o panorama da violência juvenil. A Educação profissional } \\
\text { como forma de inclusão. A percepção de si mesmo e do outro. Programas e projetos que } \\
\text { garantam inclusão de menores em situação de risco. O acesso e permanência no PROEJA. } \\
\text { O tratamento das diversidades de gênero, raça, religião nos programas educacionais. } \\
\text { Princípios pedagógicos da educação como inclusão. }\end{array}$ \\
\hline & $\begin{array}{l}\text { Pesquisa e Produção } \\
\text { em PROEJA-15h }\end{array}$ & $\begin{array}{l}\text { Orientação específica para elaboração do Projeto de Pesquisa referente à monografia do } \\
\text { Curso de Especialização modalidade EJA e PROEJA. Preparação de artigos e resumos para } \\
\text { congressos; normas técnicas (ABNT); interpretação de gráficos e tabelas. Elaboração de um } \\
\text { seminário. }\end{array}$ \\
\hline Monografia & & \\
\hline
\end{tabular}

Fonte: Elaboração a partir do projeto de curso (IFSC, 2009).

\section{Constatamos que os conteúdos dos eixos da Proposta de Curso de} Especialização do PROEJA (BRASIL, 2006a) estão presentes nos módulos e componentes curriculares de forma reordenada e ressignificada, num movimento claro de adaptação às prescrições advindas da SETEC/MEC, colocando, no entanto, vários elementos novos nas ementas dos componentes curriculares, ampliando as possibilidades de formação docente, dando ênfase à interdisciplinaridade que está presente em

Olh@res, Guarulhos, v. 2, n. 2, p. 154-178. Dezembro, 2014. 
diferentes módulos. Nesse sentido, cabe destacar que, ao ampliar o eixo de gestão democrática, esta Unidade-Polo também evidencia sua preocupação com os sujeitos da EJA no PROEJA.

Um problema identificado foi uma mesma ementa para dois componentes curriculares de módulos distintos. O componente curricular "Avaliação de aprendizagem: Diagnósticos X Classificação", com carga horária de 30 horas do Módulo 1, e o componente curricular "Planejamento, sistematização e avaliação do trabalho educativo", com carga horária de 15 horas do Módulo 2, trazem a seguinte ementa: Concepção e princípios do trabalho educativo. Relações entre objetivos, métodos, organização dos tempos e espaços e avaliação do trabalho educativo. Avaliação processual da aprendizagem e avaliação da ação planejada. Por outro lado, a temática da relação entre Trabalho e Educação que deve permear toda a formação, tendo em vista o trabalho ser tomado como princípio educativo, está contemplada em dois componentes curriculares: Eixos, Princípios e Políticas de Educação, Processos Pedagógicos, Ciência, Trabalho e Tecnologia; e Economia Solidária, o que constitui uma positividade.

A preocupação com as condições de aprendizagem dos sujeitos da EJA é também outra positividade evidenciada no destaque que é dado à construção de materiais didático-pedagógicos voltados às práticas docentes relacionadas à ciência, ao trabalho e tecnologia, à linguística e à matemática no PROEJA presentes no eixo 3, que trata da didática, cujo foco esteve voltado à ação docente, aos processos de aprendizagem e à educação básica na modalidade EJA. Neste sentido, o projeto apresenta a metodologia caracterizada da seguinte maneira:

As práticas pedagógicas abordam de forma integrada diferentes temas que procuram provocar um conjunto de reflexões sistemáticas que levam a um permanente diálogo entre todos os envolvidos. Portanto, um enfoque pertinente atrelado à prática metodológica do curso é a ênfase no aprendizado construído de forma dialética, que busca em especial contribuir para ressignificar a história escolar dos alunos da EJA. Importante também salientar que a base do trabalho de articulação entre o saber prático e teórico desse curso é a formação de educadores para trabalhar com a integração entre a educação de base e o ensino profissionalizante. As estratégias pedagógicas e metodológicas buscam dar concretude ao conhecimento construído e potencializar uma educação praxiológica na formação dos alunos. [...] $\mathrm{Na}$ prática desta proposta, será feita uma articulação a partir de eixos conceituais. $\mathrm{O}$ trabalho pauta-se nessa inter-relação que se dá por meio de conceitos discutidos em cada

Olh@res, Guarulhos, v. 2, n. 2, p. 154-178. Dezembro, 2014. 
componente curricular e culminará com os laboratórios pedagógicos presentes em cada módulo (IFSC, 2009, p. 19).

A Unidade-Polo do consórcio do Rio Grande do Sul tem uma peculiaridade: as turmas estão vinculadas às IES que fazem parte do consórcio de instituições que ofertam o curso de Especialização do PROEJA no Estado. Cada instituição do consórcio tem a liberdade de introduzir novas disciplinas e conteúdos de ensino e apresentam diferenças na ofertade disciplinas, mas preservando a carga horária de 375 horas. No entanto, a distribuição da carga horária também é diferenciada entre os módulos e disciplinas, o que procuramos manter e especificar no quadro que apresentamos a seguir.

Quadro 4 - O curso de especialização do PROEJA na Unidade-Polo do Rio Grande do Sul

\begin{tabular}{|c|c|c|}
\hline MÓDULOS & $\begin{array}{l}\text { DISCIPLINAS } \\
\end{array}$ & EMENTAS \\
\hline \multirow{7}{*}{$\begin{array}{l}\text { Módulo I } \\
\text { Matriciamentos da formação docente } \\
\text { Total } 115 \text { h/a (base geral dos programas } \\
\text { de Bento Gonçalves e Porto Alegre) }\end{array}$} & $\begin{array}{l}\text { Seminário de Integração I - Formação } \\
\text { de Docentes e Gestores - o PROEJA: } \\
10 \mathrm{~h}\end{array}$ & $\begin{array}{l}\text { Apresentação e reflexões sobre o Projeto Pedagógico do } \\
\text { Curso de Formação de Docentes e Gestores no Âmbito } \\
\text { do Programa Nacional de Integração da Escola } \\
\text { Profissional com a Educação Básica na Modalidade de } \\
\text { Educação de Jovens e Adultos - PROEJA. Dinâmica de } \\
\text { integração e acolhida aos alunos e professores do Curso }\end{array}$ \\
\hline & $\begin{array}{l}\text { Currículo e Avaliação no PROEJA - } \\
45 \text { h/a (nas turmas de Porto Alegre, } \\
\text { Bento Gonçalves e Júlio de Castilhos) }\end{array}$ & $\begin{array}{l}\text { Especificidades teórico-conceituais em torno da temática } \\
\text { do currículo, destacando o tema da avaliação como } \\
\text { ingrediente da construção curricular e aperfeiçoamento } \\
\text { do processo de ensino com ênfase nas peculiaridades da } \\
\text { EJA integrada ao ensino profissional. }\end{array}$ \\
\hline & $\begin{array}{l}\text { Teorias de Currículo e a Organização } \\
\text { da Prática Educativa Interdisciplinar } \\
\text { na Educação de Jovens e Adultos, na } \\
\text { Educação Profissional e na Educação } \\
\text { Básica - 30h/a. (Nas turmas de Santa } \\
\text { Maria e São Vicente do Sul) }\end{array}$ & $\begin{array}{l}\text { História e teorias do currículo. Currículos e programas } \\
\text { no Brasil. Currículo na EJA: abordagem temática e } \\
\text { interdisciplinariedade. Organização da prática educativa } \\
\text { Interdisciplinar e as interfaces na EJA, no Ensino Médio } \\
\text { e na Educação Profissional. }\end{array}$ \\
\hline & $\begin{array}{l}\text { Educação e as Tecnologias da } \\
\text { Comunicação - 30h/a. (Nas turmas de } \\
\text { São Vicente do Sul e Alegrete) }\end{array}$ & $\begin{array}{l}\text { Internet. Sociedade da informação. } \\
\text { Informação. Redes de comunão. } \\
\text { Infação. Ciência. }\end{array}$ \\
\hline & $\begin{array}{l}\text { História da Escolarização no Brasil: } \\
\text { ênfase na Educação de Jovens e } \\
\text { Adultos, na Educação Profissional - } \\
\text { 30h/a. (Nas turmas de Porto Alegre, } \\
\text { Bento Gonçalves e Júlio de Castilhos) }\end{array}$ & $\begin{array}{l}\text { Estudo analítico sobre a produção e a reprodução da } \\
\text { escola no Brasil pela Modernidade, compreensão das } \\
\text { principais visões pedagógicas e práticas educativas } \\
\text { desenvolvidas no Brasil desde a colonização até a } \\
\text { atualidade com ênfase na História da EJA, da Educação } \\
\text { Profissional e do Ensino Médio. }\end{array}$ \\
\hline & $\begin{array}{l}\text { Perspectiva histórica e desafios atuais } \\
\text { na Educação de Jovens e Adultos e na } \\
\text { Educação Profissional: 45h/a. ( } \mathrm{Na} \\
\text { turma de Alegrete) }\end{array}$ & Idem \\
\hline & $\begin{array}{l}\text { Psicologia da Adolescência e Vida } \\
\text { Adulta - 30h/a. (Não ocorre no } \\
\text { programa de Santa Maria) }\end{array}$ & $\begin{array}{l}\text { Desenvolvimento psicológico na adolescência e vida } \\
\text { adulta, incluindo a velhice: conceitos, características e } \\
\text { processos segundo diferentes abordagens teóricas. }\end{array}$ \\
\hline
\end{tabular}

Olh@res, Guarulhos, v. 2, n. 2, p. 154-178. Dezembro, 2014. 


\begin{tabular}{|c|c|c|}
\hline & $\begin{array}{l}\text { Educação e Trabalho - } 30 \mathrm{~h} / \mathrm{a} . \\
\text { (Nas turmas de Santa Maria, Porto } \\
\text { Alegre, Bento Gonçalves, Júlio de } \\
\text { Castilhos e Alegrete) }\end{array}$ & $\begin{array}{l}\text { Modo de produção capitalista, Trabalho e Educação. } \\
\text { Mudanças no mundo do trabalho. Saberes produzidos no } \\
\text { e sobre o trabalho. Os sujeitos e suas trajetórias. Espaços } \\
\text { de articulação entre escola e trabalho e a influência das } \\
\text { redes de pertencimento como legitimação e valorização } \\
\text { dos sujeitos e seus saberes. }\end{array}$ \\
\hline & $\begin{array}{l}\text { Invenções e intervenções pedagógicas } \\
-10 \mathrm{~h} / \mathrm{a} \text {. }\end{array}$ & $\begin{array}{l}\text { Reflexões da/sobre a prática pedagógica e educativa a } \\
\text { partir das experiências e vivências de cada educador. } \\
\text { Saberes necessários à prática educativa. }\end{array}$ \\
\hline \multirow{6}{*}{ 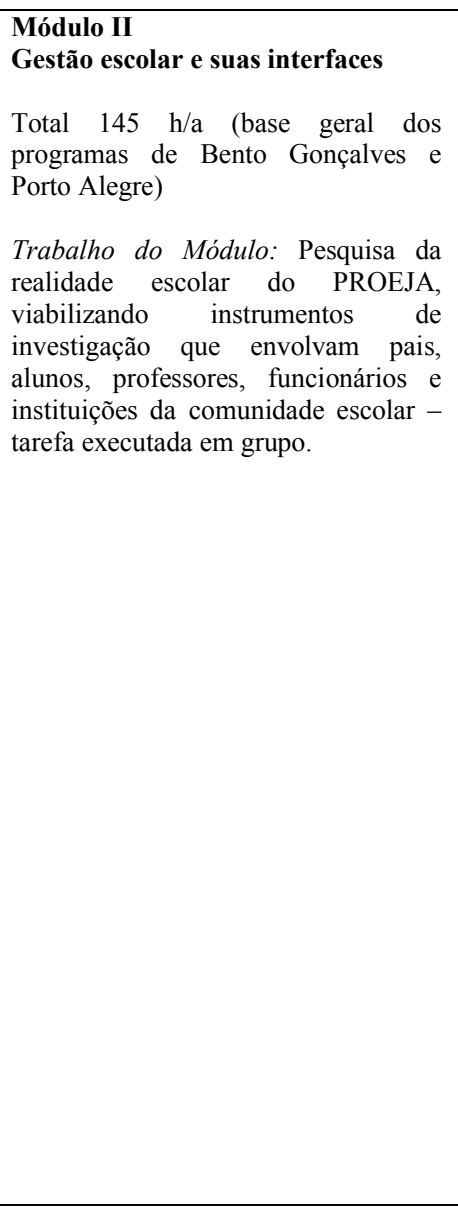 } & $\begin{array}{l}\text { Políticas sociais e políticas } \\
\text { educacionais - } 45 \mathrm{~h} / \mathrm{a} \text { (Nas turmas de } \\
\text { Porto Alegre e Bento Gonçalves) }\end{array}$ & $\begin{array}{l}\text { A organização das políticas sociais no Brasil diante da } \\
\text { atual crise do emprego. Políticas educacionais e suas } \\
\text { interfaces na EJA, no Ensino Médio e na Educação } \\
\text { Profissional. }\end{array}$ \\
\hline & $\begin{array}{l}\text { Políticas educacionais e a gestão da } \\
\text { escola }-30 \mathrm{~h} / \mathrm{a} \text {. }\end{array}$ & $\begin{array}{l}\text { Estudo teórico-prático da organização da escola como } \\
\text { mediadora de políticas, de concepções e práticas } \\
\text { pedagógicas. Modelos organizacionais e de tempo- } \\
\text { espaço na escola pública, democrática e de qualidade. } \\
\text { Organização curricular da escola: exigências } \\
\text { normativas, autonomia, papel dos diferentes atores e } \\
\text { suas relações no pensar-fazer do projeto pedagógico - } \\
\text { tempos e espaços escolares, componentes } \\
\text { curriculares/avaliação. A gestão democrática da escola: } \\
\text { autonomia pedagógica, financeira e administrativa. A } \\
\text { escola e suas interfaces. }\end{array}$ \\
\hline & $\begin{array}{llll}\text { Metodologia de } & \text { Pesquisa } & \text { em } \\
\text { Educação }-30 \text { h/a. } & & \end{array}$ & $\begin{array}{l}\text { A construção do objeto de pesquisa em Educação: } \\
\text { motivações, delimitação do problema de pesquisa, } \\
\text { delineamento teórico. A abordagem quantitativa com a } \\
\text { utilização e interpretação de dados estatísticos. }\end{array}$ \\
\hline & $\begin{array}{l}\text { Projetos político-pedagógicos - 30h/a. } \\
\text { (Não ofertada em Alegrete) }\end{array}$ & $\begin{array}{l}\text { Processos de construção, elaboração e análise de } \\
\text { projetos político-pedagógicos. A dimensão coletiva do } \\
\text { projeto político-pedagógico. Autonomia, } \\
\text { responsabilidade e identidade da escola e do projeto } \\
\text { político-pedagógico enquanto expressão de um projeto } \\
\text { de sociedade. O projeto político-pedagógico como } \\
\text { instrumento e ferramenta de gestão compartilhada e } \\
\text { democrática da escola. }\end{array}$ \\
\hline & $\begin{array}{l}\text { Trajetórias e saberes docentes na } \\
\text { Educação de Jovens e Adultos, na } \\
\text { Educação Profissional e no Ensino } \\
\text { Médio - } 30 \text { h/a. (Nas turmas de Santa } \\
\text { Maria, São Vicente do Sul, Porto } \\
\text { Alegre, Bento Gonçalves e Júlio de } \\
\text { Castilhos) }\end{array}$ & $\begin{array}{l}\text { Matrizes, modelos, referências e espelhamentos da } \\
\text { constituição da docência na pessoa. Processos de } \\
\text { afirmação e identificação do ser e do saber docente nas } \\
\text { trajetórias de vida de professores. Bases curriculares da } \\
\text { EJA, da Educação Profissional e do Ensino Médio. }\end{array}$ \\
\hline & $\begin{array}{l}\text { Invenções e intervenções pedagógicas } \\
-10 \mathrm{~h} / \mathrm{a} \text {. }\end{array}$ & $\begin{array}{l}\text { Trocas de experiências pedagógicas e } \text { e articulação } \\
\text { teórico-prática da ação e intervenção educativa do } \\
\text { professor na escola. }\end{array}$ \\
\hline \multirow{3}{*}{$\begin{array}{l}\text { Módulo III } \\
\text { Experiências inovadoras na } \\
\text { Educação Profissional, na Educação } \\
\text { de Jovens e Adultos e na Educação } \\
\text { Básica } \\
\text { Total 115h/a (base geral dos } \\
\text { programas de Bento Gonçalves e } \\
\text { Porto Alegre) } \\
\text { Trabalho do Módulo: Apresentação } \\
\text { de sua ideia / intenção de pesquisa } \\
\text { para o trabalho de conclusão da } \\
\text { Especialização - seminário geral da } \\
\text { turma }\end{array}$} & $\begin{array}{l}\text { Sujeitos da Educação: gênero, } \\
\text { etnicidade, questões geracionais, } \\
\text { éticas, religiosas, pessoas com } \\
\text { necessidades educativas especiais, } \\
\text { trabalho e geração de renda - 30h/a. } \\
\text { (Nas turmas de Porto Alegre e Bento } \\
\text { Gonçalves e Júlio de Castilhos) }\end{array}$ & $\begin{array}{l}\text { Entendimento do sujeito da Educação e sua experiência } \\
\text { concreta em alternativas de geração de trabalho e renda, } \\
\text { cotejando gênero, etnia, geração, éticas religiosas como } \\
\text { constitutivas e constituintes desse sujeito. }\end{array}$ \\
\hline & 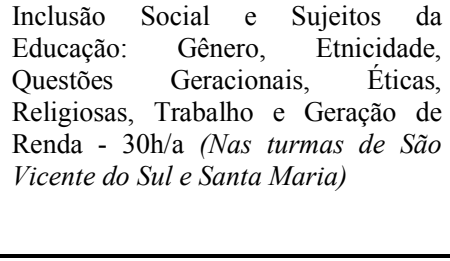 & $\begin{array}{l}\text { Entendimento do sujeito da Educação e sua experiência } \\
\text { concreta em alternativas de geração de trabalho e renda, } \\
\text { cotejando gênero, etnia, geração, éticas religiosas como } \\
\text { constitutivas e constituintes desse sujeito. (idêntico ao } \\
\text { que consta na ementa anterior). Orientação do } \\
\text { preenchimento do cadastro de experiências alternativas } \\
\text { - trabalho final do módulo. }\end{array}$ \\
\hline & $\begin{array}{l}\text { A Escola e a ética do cuidado - } 30 \mathrm{~h} / \mathrm{a} . \\
\text { (Nas turmas de Porto Alegre e Bento } \\
\text { Gonçalves e Júlio de Castilhos) }\end{array}$ & $\begin{array}{l}\text { Reflexão à luz da teoria de Edgar Morin sobre os } \\
\text { desafios e conceitos como movimento, organização, } \\
\text { desordem e complexidade trazem para uma disposição } \\
\text { ético-estético-afetiva que perceba a educação como } \\
\text { processo intercultural de humanização e gestão do } \\
\text { cuidado. }\end{array}$ \\
\hline
\end{tabular}

Olh@res, Guarulhos, v. 2, n. 2, p. 154-178. Dezembro, 2014. 


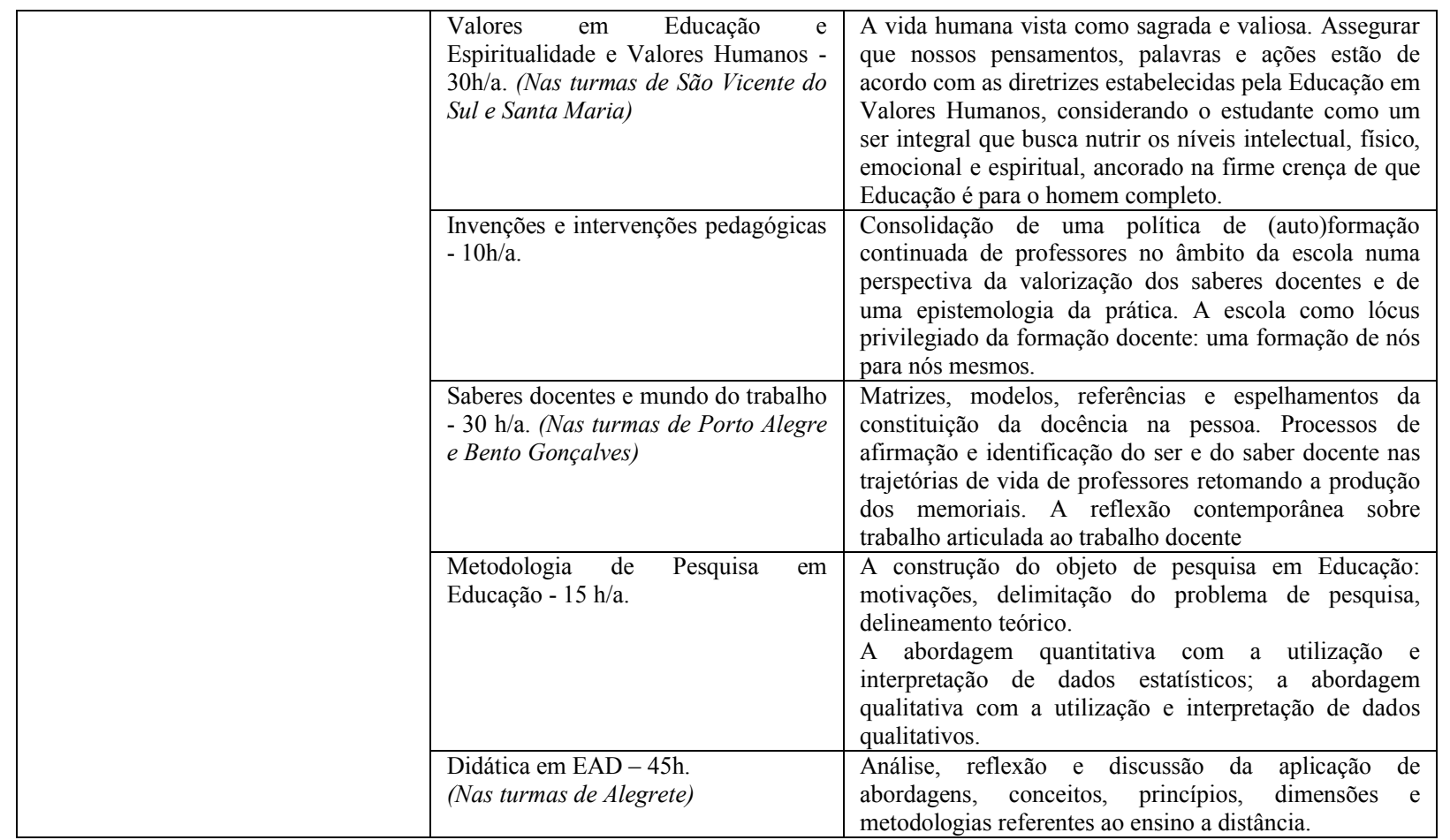

Fonte: Elaboração a partir do projeto de curso (UFRGS, 2007).

Portanto, neste projeto pedagógico encontramos a organização curricular em três módulos, e os conteúdos dos cinco eixos da Proposta de Curso de Especialização do PROEJA pulverizados nestes três módulos, no entanto, apresentando algumas lacunas e fragilidades.

Embora possamos entender a postura das instituições como uma busca por dar um enfoque próprio e uma ênfase diferenciada ao seu projeto pedagógico, é possível perceber que algumas disciplinas estão em desarmonia com a proposta da SETEC e também com o anunciado no projeto pedagógico das IES, como é o caso da disciplina "Valores em Educação e Espiritualidade e Valores Humanos", com 30 horas aula, e da disciplina "Didática em EAD”, que vai tratar de "abordagens, conceitos, princípios, dimensões e metodologias referentes ao ensino a distância” com 45 horas na turma de Alegrete.

Por outro lado, uma positividade é a presença da temática da relação educação e trabalho contemplada na disciplina "Educação e Trabalho", com carga horária de 30 horas ofertada nos campi de Santa Maria, Porto Alegre, Bento Gonçalves, Júlio de Castilhos e Alegrete. E na disciplina "Saberes 
docentes e mundo do trabalho", com carga horária de 30 horas, nos campi Porto Alegre e Bento Gonçalves. A presença da disciplina Educação e Trabalho, também constatada no projeto pedagógico da UTFPR, é relevante por permitir a discussão das mudanças ocorridas no mundo do trabalho, algo fundamental de ser tratado na formação de professores que atuam naeducação profissional. Neste sentido, a reflexão de Kuenzer (2011), enfatiza sua importância:

\begin{abstract}
Outra dimensão a considerar na formação dos professores diz respeito à mudança de eixo que ocorre na passagem do taylorismo/fordismo para as novas formas de organização e gestão dos processos sociais e produtivos, no que se refere à relação entre homem e conhecimento, que agora não passa mais pelos modos de fazer, como memorização e repetição de procedimentos relativamente rígidos e estáveis. Pelo contrário, essa relação passa agora pelas atividades intelectuais, exigindo o desenvolvimento de competências cognitivas que só se desenvolvem em situações de aprendizagem que possibilitem interação significativa e permanente entre o aluno e o conhecimento. Em decorrência, torna-se necessário não só o trato com conteúdos, mas principalmente com formas metodológicas que permitam a utilização do conhecimento sócio-histórico e científico-tecnológico para intervir na realidade, criando novos conhecimentos (KUENZER, 2011, p. 684).
\end{abstract}

No entanto, nessa organização curricular adotada pela Unidade-Polo do Rio Grande do Sul, constatamos a ausência de disciplinas que tratam do eixo "Didáticas na Educação Profissional e na Educação de Jovens e Adultos", constituindo-se numa fragilidade dessa formação docente. O conteúdo programático desse eixo está especificamente voltado aos fundamentos da atuação e da prática docente na condução do ensino e da aprendizagem em sala de aula, sendo imprescindível para a atuação docente. Nesse sentido, entendemos, como IMBERNÓN (2007), que

No se trata, pues, de aprender un oficio en el que predominan estereotipos y técnicas predeterminadas sino que se trata de aprender los fundamentos de una cultura profesional, lo que quiere decir saber por qué se hace lo que se hace, y cuándo y por qué será necesario hacerlo de un modo distinto (IMBERNÓN, 2007, p. 55).

Como inexiste outra disciplina que trata de metodologias ou estratégias de ensino, isso evidencia que não foram tratados no curso de especialização do PROEJA da Unidade-Polo do consórcio do Rio Grande do Sul conteúdos relativos aos fundamentos didáticos sobre os modos de ensinar para jovens e adultos no PROEJA. Trata-se de uma lacuna Olh@res, Guarulhos, v. 2, n. 2, p. 154-178. Dezembro, 2014. 
justamente em um aspecto determinante, constituindo-se em uma fragilidade na oferta dessa formação. A didática é responsável pelo conhecimento profissional pedagógico específico da formação docente. Essa lacuna também foi evidenciada na pesquisa de campo que será tratada no próximo capítulo.

Outra lacuna percebida no projeto de Curso de Especialização do PROEJA da Unidade-Polo do consórcio do Rio Grande do Sul diz respeito ao quadro legal das áreas envolvidas, que não foi contemplado em seu projeto pedagógico. Entendemos ser fundamental a abordagem histórica dos marcos legais da educação básica na modalidade de educação de jovens e adultos, do ensino médio integrado e da educação profissional técnica de nível médio e da formação inicial e continuada, bem como da Lei de Diretrizes e Bases da Educação Nacional, para se compreender a fundamentação legal dessas ofertas de educação, além de compreender as concepções e princípios que as embasam.

\section{Considerações finais}

A análise realizada nos permitiu perceber algumas contradições presentes em cada um dos projetos das três Unidades-Polo. A contradição mais determinante é a IES acatar e explicitar os mesmos objetivos gerais e específicos, e a concepção deste programa de formação docente sugerida pela SETEC/MEC, para em seguida, na organização curricular, que é onde a concepção e os objetivos vão se concretizar, estes se organizarem não mais em eixos, mas se fragmentarem em unidades curriculares e disciplinas. Mesmo quando em seus projetos pedagógicos a Unidade-Polo da UTFPR e a Unidade-Polo do IFSC expressam em suas matrizes curriculares os eixos, a grande fragmentação em unidades curriculares permite afirmar que esta organização dos conteúdos não contempla a organização curricular em eixos e fragiliza a formação.

Assim, podemos afirmar que a forma que as Unidades-Polo adotaram para organizar suas propostas pedagógicas não foi tão somente um

Olh@res, Guarulhos, v. 2, n. 2, p. 154-178. Dezembro, 2014. 
exercício de afirmação de autonomia das IES, tendo em vista a Proposta de Curso de Especialização do PROEJA (BRASIL, 2006a) ter sido encaminhada como sugestão pela SETEC/MEC, mas pode ser entendida como um movimento de resistência à concepção do PROEJA e da formação integrada, caracterizando-se numa aceitação aparente e não concreta e real do programa. Ou seja, o fato de as IES terem respondido positivamente aos editais e, em parte, à Proposta de Curso de Especialização do PROEJA da SETEC/MEC não significou que as orientações presentes nestes documentos e, consequentemente, os compromissos propostos com a formação docente para a atuação no PROEJA tenham sido efetivamente assumidos. A este fato se deve em parte as lacunas e contradições encontradas nas propostas pedagógicas das Unidades-Polo, em nossa análise.

Entendemos que o distanciamento e a incoerência entre o que está declarado e prescrito como proposta curricular em um documento e o que é efetivamente desenvolvido nas unidades de ensino, em algumas situações, faz com que o que é encontrado nos projetos pedagógicos nem sempre seja o que é praticado, visto que um currículo não significa o engessamento da atividade docente.

Concluímos que com o PROEJA a formação de professores da Educação Profissional e da Educação de Jovens e Adultos recebeu significativos investimentos do governo federal, mas não recebeu o equivalente acompanhamento da SETEC/MEC em sua implantação e desenvolvimento, o que pode ter contribuído para que as incoerências constatadas se fizessem presentes no interior dos projetos pedagógicos, mas também revelou a fragilidade das universidades na organização e oferta de formação continuada aos professores, especialmente quando se trata de um programa de formação docente específico.

Olh@res, Guarulhos, v. 2, n. 2, p. 154-178. Dezembro, 2014. 


\section{Referências}

BRASIL. Programa Nacional de Integração da Educação Profissional Técnica de nível médio ao Ensino Médio na Modalidade de Educação de Jovens e Adultos - PROEJA. Documento Base. Brasília: MEC/SETEC, 2006a.

Capacitação de profissionais do ensino público para atuar na educação profissional técnica de nível médio integrada ao Ensino Médio na modalidade EJA. Propostas Gerais para Elaboração de Projetos Pedagógicos de Curso de Especialização. Brasília: MEC/SETEC, 2006b (mimeo).

BURNIER, S.; CUNHA, F. M. Estrutura curricular por eixos de conteúdos e atividades. Revista de Ensino de Engenharia. Brasília: Associação Brasileira de Educação em Engenharia, v. 24, n. 2, p. 35-42, 2005.

IFSC. Projeto de Curso de Especialização em Educação Profissional Integrada à Educação Básica na Modalidade Educação de Jovens e Adultos - Pós-graduação lato sensu. Florianópolis: Instituto Federal de Educação, Ciência e Tecnologia de Santa Catarina, 2009.

IMBERNÓN, F. La formación y el desarrollo profesional del profesorado: hacia una nueva cultura profesional. Barcelona: Graó, 2007.

KUENZER, A. Z. A formação de professores para o ensino médio: velhos problemas, novos desafios. Educação e Sociedade. Campinas, v. 32, n. 116, p. 667-688, jul.-set. 2011.

LIMA FILHO, D. L. Projeto de Pesquisa: Título. Projeto de Pesquisa n. 9. Edital PROEJA CAPES/SETEC n. ${ }^{\circ}$ 3/2006. Curitiba: UTFPR/UFPR/UNIOESTE, 2007.

MARON, N. M. W. Os cursos de especialização para formação docente do PROEJA: a tecitura da oferta e dos resultados na percepção de cursistas da região sul do Brasil. Tese (Doutorado). Curitiba: Universidade Tecnológica Federal do Paraná. Programa de Pósgraduação em Tecnologia, 2013.

UFRGS. Projeto de Curso de Especialização em Educação Profissional Integrada à Educação Básica na Modalidade Educação de Jovens e Adultos - Pós-Graduação lato sensu. Porto Alegre: UFRGS/CEFETBG/CEFETSVS/UFSM, 2007.

UTFPR. Projeto de Curso de Especialização em Educação Profissional Integrada à Educação Básica na Modalidade Educação de Jovens e Adultos - Pós-Graduação lato sensu. Curitiba: Universidade Tecnológica Federal do Paraná, 2006.

2010.

Relatório Circunstanciado. Curitiba: Universidade Tecnológica Federal do Paraná,

Olh@res, Guarulhos, v. 2, n. 2, p. 154-178. Dezembro, 2014. 